\title{
Hydrological differences between the Lutetian Paris and Hampshire basins revealed by stable isotopes of conid gastropods
}

\author{
Alexander J. Clark ${ }^{1, *}$ (D), Johan Vellekoop ${ }^{1,2}$ (B) and Robert P. Speijer ${ }^{1}$ (D) \\ ${ }^{1}$ Department of Earth and Environmental Sciences, KU Leuven, Celestijnenlaan 200E, 3001 Heverlee, Belgium \\ 2 Analytical, Environmental and Geochemistry research group, Vrije Universiteit Brussel, Pleinlaan 2, 1050 Brussels, Belgium
}

Received: 5 February 2021 / Accepted: 1 February 2022 / Publishing online: 14 March 2022

\begin{abstract}
During the Eocene greenhouse (56.0-33.9 Ma), northwest Europe was dominated by a semiarid para-tropical climate but the paleohydrological conditions are poorly known. To gain more insight into seasonal hydrological conditions in the region, we compare Lutetian (middle Eocene, $\sim 44-45 \mathrm{Ma}$ ) mollusk $\delta^{18} \mathrm{O}$ records from two shallow marine basins on either side of the English Channel, i.e., the Paris and Hampshire Basins. The semi-circular Paris Basin was open to the Atlantic Ocean, while the Hampshire Basin was more enclosed and influenced by the draining of several rivers. The proximity of the basins and the similarity of their faunal assemblages suggest that they experienced roughly similar seawater temperatures but the seasonal hydrology is expected to have been different between these basins. Among the numerous mollusks present in both basins are several members of Conidae, a gastropod family that is particularly well-suited for paleoseasonality reconstructions. To assess the paleohydrological differences between these basins we analyzed the stable oxygen isotopic composition of three specimens of Eoconus deperditus from the Banc à Verrains in the middle part of the Calcaire Grossier Formation of the Paris Basin (France), and three specimens of Eoconus edwardsi from the Shepherd's Gutter Bed in the upper part of the Selsey Formation of the Hampshire Basin (United Kingdom). While the seasonal variability appears to have been similar between these basins, the $\delta^{18} \mathrm{O}$ values of the Hampshire Basin specimens are consistently lower than those in the Paris Basin, suggesting a regional difference in $\delta^{18} \mathrm{O}_{\mathrm{sw}}$ of $1-2 \%$ between the basins. This difference in $\delta^{18} \mathrm{O}_{\mathrm{sw}}$ was likely related to the greater influence of fluvial discharge within the Hampshire basin, compared to the Paris Basin.
\end{abstract}

Keywords: Conidae / paleohydrology / Lutetian

Résumé - Différences hydrologiques des bassins Lutétiens de Paris et du Hampshire révélée par les isotopes stables des gastéropodes conids. Durant la période de l'Éocène (56,0-33,9 Ma), il est établi que le Nord-Ouest de l'Europe était dominé par un climat para-tropical, semi-aride, mais les conditions paléohydrologiques sont peu connues. Afin de mieux déterminer les conditions hydrologiques saisonnières dans la région, nous comparons les enregistrements $\delta^{18} \mathrm{O}$ de mollusques Lutétiens (Éocène moyen, $\sim 44-45 \mathrm{Ma}$ ) issus de deux bassins marins peu profonds de part et d'autre de la Manche : les bassins de Paris et du Hampshire. Le bassin semi-circulaire de Paris était ouvert sur l'océan Atlantique, tandis que le bassin du Hampshire était plus fermé et influencé par le drainage de plusieurs rivières. La proximité de ces bassins suggère qu'ils ont connu des températures d'eau de mer relativement similaires, mais l'hydrologie saisonnière pourrait avoir été fort différente entre ces bassins. Parmi les nombreux mollusques présents dans les deux bassins, on trouve plusieurs membres des Conidae, une famille de gastéropodes particulièrement adaptée aux reconstitutions de la paléo-saisonnalité. Afin d'évaluer les différences paléohydrologiques entre ces bassins, nous avons analysé la composition isotopique stable de l'oxygène $\left(\delta^{18} \mathrm{O}\right)$ de trois spécimens d'Eoconus deperditus du Banc à Verrains situé dans la partie centrale de la Formation de Calcaire Grossier du bassin de Paris (France), et de trois spécimens d'Eoconus edwardsi du lit de la Shepherd's Gutter Bed dans la partie supérieure de la Formation de Selsey du bassin du Hampshire (Royaume-Uni). Bien que la variabilité saisonnière semble avoir été similaire dans ces deux bassins, les valeurs de $\delta^{18} \mathrm{O}$ des spécimens

*Corresponding author: alex.dino17@gmail.com 
du bassin du Hampshire sont systématiquement inférieures à celles du bassin de Paris, ce qui suggère une différence régionale de $1-2 \%$ entre les bassins. Cette différence de $\delta^{18} \mathrm{O}_{\mathrm{sw}}$ était probablement liée à la plus grande influence du débit fluvial dans le bassin du Hampshire, comparé au bassin de Paris.

Mots clés : Conidae / paléohydrologie / Lutétien

\section{Introduction}

The Lutetian age (48.07-41.03 Ma; Speijer et al., 2020) was one of the last times the world experienced high temperatures and $\mathrm{CO}_{2}$ levels (Zachos et al., 2008; Rae et al., 2021). Accordingly, the Lutetian climate could serve as a potential analogue for future climate states (Tierney et al., 2020; Westerhold et al., 2020). So far, most Lutetian paleoclimate records show long-term temperature changes, e.g., on a $100 \mathrm{kyr}$ scale (Zachos et al., 2008; Barron et al., 2015). Short-term (intra-annual to decadal) climate and weather phenomena are less well-constrained for this time interval than longer-term climate records. In particular paleohydrological conditions are poorly known, as hydroclimate reconstructions of the past are considered particularly challenging because proxy signals tend to be more complex (Tierney et al., 2020). A potentially promising approach to gain more insight in seasonal, regional hydrological variability under Eocene greenhouse conditions, is to compare mollusk $\delta^{18} \mathrm{O}$ records from neighboring regions that experienced roughly similar seawater temperatures. Mollusks incorporate oxygen isotopes into their carbonate shell in equilibrium with the surrounding seawater (Grossman and Ku, 1986; Lécuyer et al., 2004, 2012). As shell growth occurs incrementally, seawater temperatures and chemistry vary in response to short-term climate and weather changes. Given that the incorporated oxygen isotope composition is forced by these changing parameters, mollusk $\delta{ }^{18} \mathrm{O}$ records can be used as a proxy for sub-annual paleotemperature and hydroclimatic reconstructions (Andreasson and Schmitz, 2000; Kobashi et al., 2001). When mollusk $\delta^{18} \mathrm{O}$ records from nearby regions that experienced similar seawater temperatures are compared, one can assume that any differences in mollusk $\delta{ }^{18} \mathrm{O}$ values or patterns between the regions would be mostly related to regional differences in seawater $\delta^{18} \mathrm{O}$, rather than temperature (Latal et al., 2006). Local seawater $\delta{ }^{18} \mathrm{O}$ values are controlled by regional and local patterns in precipitation, discharge, evaporation and connections with other water masses (Keith et al., 1964; Swart et al., 1989; Zachos et al., 1994; Schmitz and Andreasson, 2001; Gat, 2010). This approach could therefore provide valuable insights in regional differences in seasonal paleohydrological conditions in the Eocene greenhouse world.

The Eocene successions of the neighboring Paris and Hampshire Basins present a suitable opportunity to test this approach. During the Lutetian, these neighboring basins likely experienced similar climatological conditions as they were only $\sim 300 \mathrm{~km}$ apart, with a latitudinal difference of less than 2 degrees (Fig. 1). When modern European paleogeography is used as an analogue, it can be assumed that such a latitudinal difference should result in a maximum temperature difference of no more than $1{ }^{\circ} \mathrm{C}$ between the two basins (Andreasson and Schmitz, 2000; Goikoetxea et al., 2009), which is usually within the error of deep time paleoclimatological studies. The similarity in Lutetian marine faunas in these basins confirms their comparable paleoenvironmental conditions (Murray and
Wright, 1974; Tracey et al., 1996; Guernet et al., 2012; Dominici and Zuschin, 2016). A semi-arid, para-tropical climate prevailed in northwest Europe during the Lutetian, with hot summers and mild winters (Andreasson and Schmitz, 1996; Collinson and Hooker, 2003; Huyghe et al., 2012a; de Winter et al., 2020a). These climate conditions are also indicated by the transitional floral assemblage of the Hampshire Basin (Collinson, 1996, 2000): the more tropical floral families that dominated the early and middle Eocene were present alongside the more temperate floral families that would later characterize the late Eocene and Oligocene (Daley, 1972; Boulter and Hubbard, 1982). Coastal Nypa mangrove swamps, now restricted to tropical Southeast Asia, were dominant along the coastlines of northwest Europe (Boulter and Hubbard, 1982; Collinson, 2000; Collinson and Hooker, 2003). Evaporative lakes on the continental plateaus surrounding the basins indicate pronounced dry and wet seasons (Thiry, 1989; Huyghe et al., 2012a).

During the Lutetian both basins were well-connected to the Atlantic. The semi-circular Paris Basin was an open shelf with extensive seagrass meadows (Merle, 2008). Water depth in the basin varied, leading to a range of sandy to clayey depositional environments (Plint, 1983; Tracey et al., 1996; Huyghe et al., 2012a). The more restricted and elongated Hampshire Basin (Plint, 1982, 1983; Gibbard and Lewin, 2003; Van Vliet-Lanoë et al., 2010) was situated on the other side of the open marine English Channel, where more turbid conditions reigned. This is in large part due to regional tectonic uplifts, likely resulting in extensive erosion and pronounced freshwater influx from numerous river inflows, leading to extensive coastal plains and sandy deposits throughout the basin (Plint, 1988; Huggett and Gale, 1997; Gibbard and Lewin, 2003). Hence, whereas differences in temperature seasonality are expected to be minor between these basins, there could have been large differences in hydrology. The Lutetian successions of the Paris and Hampshire Basins both yield rich mollusk faunas that can be used to generate $\delta^{13} \mathrm{C}$ and $\delta^{18} \mathrm{O}$ records. Members of the Conidae gastropods are common in both basins and are particularly well-suited for paleoseasonality reconstructions (Kobashi and Grossman, 2003; Tao and Grossman, 2010). Therefore, in this study stable oxygen and carbon isotope profiles were generated for six specimens of Conidae from localities within the Paris and Hampshire Basins, to obtain insights into the differences in the hydroclimate of these neighboring regions during the Lutetian.

\section{Materials and methods}

\subsection{Locations}

The studied specimens were obtained from the Fleury-laRiviere (49 $\left.06^{\prime} 11^{\prime \prime} \mathrm{N} 3^{\circ} 54^{\prime} 02^{\prime \prime} \mathrm{E}\right)$ and Damery $\left(49^{\circ} 05^{\prime} 7^{\prime \prime} \mathrm{N}\right.$ $\left.3^{\circ} 51^{\prime} 55^{\prime \prime} \mathrm{E}\right)$ localities in the Paris Basin and the Bramshaw $\left(50^{\circ} 56^{\prime} 41^{\prime \prime} \mathrm{N} 1^{\circ} 40^{\prime} 50^{\prime \prime} \mathrm{W}\right)$ locality in the Hampshire Basin 


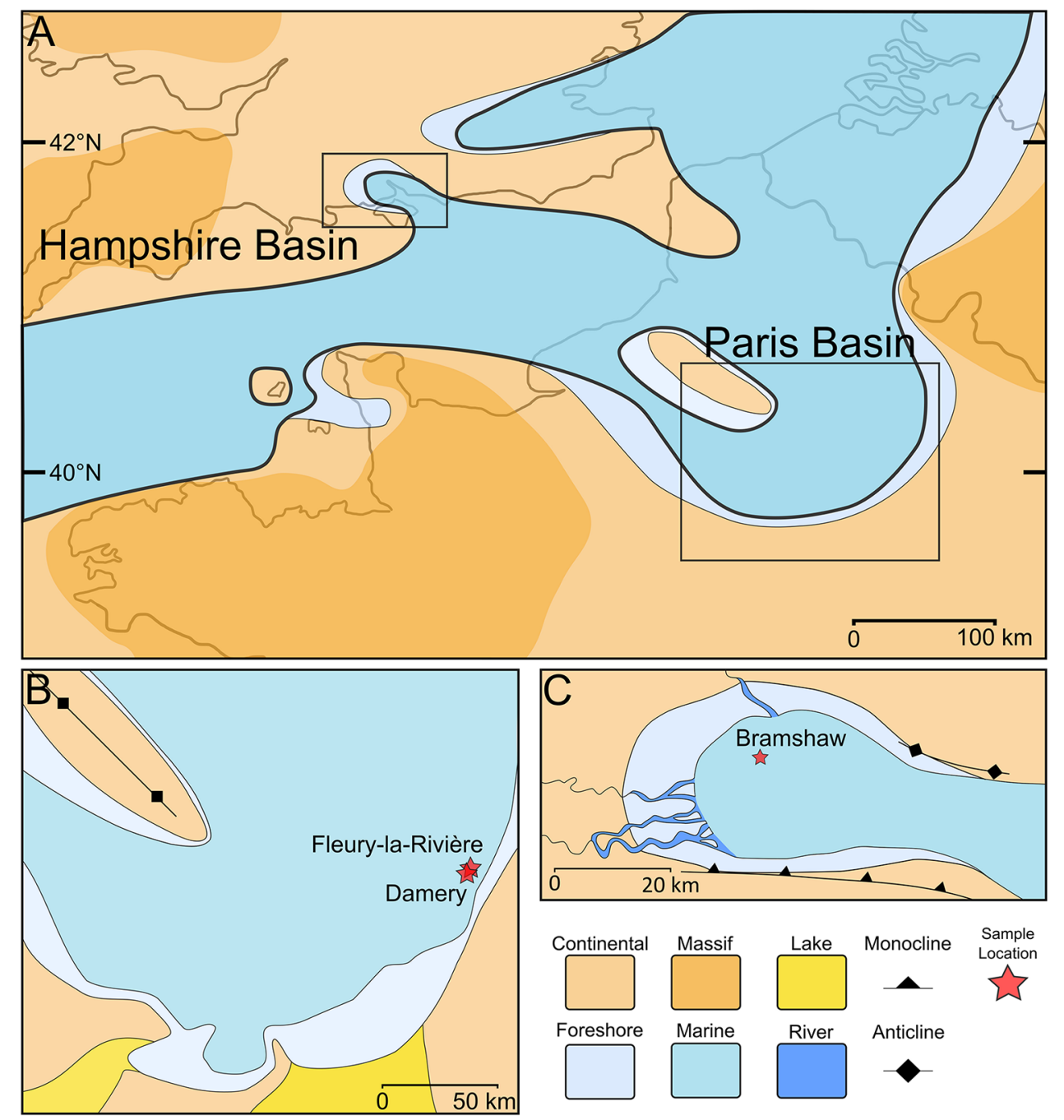

Fig. 1. (A) Paleogeography of northwest Europe with focus on the (B) Paris and (C) Hampshire Basins, based on Gibbard and Lewin (2003), Dugué et al. (2007), Van Vliet-Lanoë et al. (2010), Huyghe et al. (2012a).

(Figs. 1 and 2). The specimens from the Paris Basin are from the Banc a Verrains of the Calcaire Grossier Formation. The Fleury-la-Rivière and Damery localities are only five km apart and both comprise the middle Lutetian Banc a Verrains, also known as the main Campanile horizon (Merle, 2008; Huyghe et al., 2015; de Winter et al., 2020a). It is therefore assumed that the deposits of these sites are contemporary, dated to approximately $45 \mathrm{Ma}$, based on correlations by calcareous nannofossil biozonation (NP15) and magnetostratigraphy (Polarity Chron C20r) (Mégnien and Mégnien, 1980; Huyghe et al., 2015; King, 2016).

The faunal assemblage of the Banc a Verrains at Fleury-laRivière and Damery is dominated by turritellids (Sigmesalia and Haustator), carditids (Cyclocarida and Venericarda), cerithiids, glycymeridids, a variety of neogastropods (e.g., Sycostoma, Athleta, Clavilithes and Turricula) and bryozoans (Lunulites; Huyghe et al., 2015; Sanders et al., 2015; Dominici and Zuschin, 2016). The faunal assemblages and sedimentology suggest a sandy bottom with abundant macroalgae, at shallow subtidal water depths of 5-10 $\mathrm{m}$, with a maximum depth no greater than $20 \mathrm{~m}$ (Huyghe et al., 2012a; de Winter et al., 2020a)
The specimens from the Bramshaw locality are from the Shepherd's Gutter Bed of the Selsey Formation (Norvick, 1969; Stinton, 1969; Barnet, 2021). Correlation using dinoflagellate cysts, calcareous nannofossils and the occurrence of nummulites within the Hampshire Basin dates this bed to approximately $44 \mathrm{Ma}$, within the lower NP16 biozone (King, 2016). While there is a $\sim 1 \mathrm{Ma}$ difference, regional climatic conditions were similar over this period of time (Huyghe et al., 2015; Dominici and Zuschin, 2016) and thus potential differences due to time between the localities is considered to be minimal. The paleolatitude is estimated to be $40^{\circ} \mathrm{N}$ for the Paris Basin localities and a slightly more northern paleolatitude of $42^{\circ} \mathrm{N}$ for the Hampshire Basin locality (van Hinsbergen et al., 2015).

The faunal assemblage of the Shepherd's Gutter Bed at Bramshaw is quite similar to that of the Banc a Verrains at Fleury-la-Rivière and Damery, with an abundance of turritellids (Torquesia), carditids (Cyclocarida and Venericarda) and conids (Eoconus edwardsi) and a variety of other neogastropods (e.g., Bathytoma, Sycostoma, Athleta, Clavilithes and Turricula), pectinids (Lentipecten) and occasional 
Paris Basin

Hampshire Basin

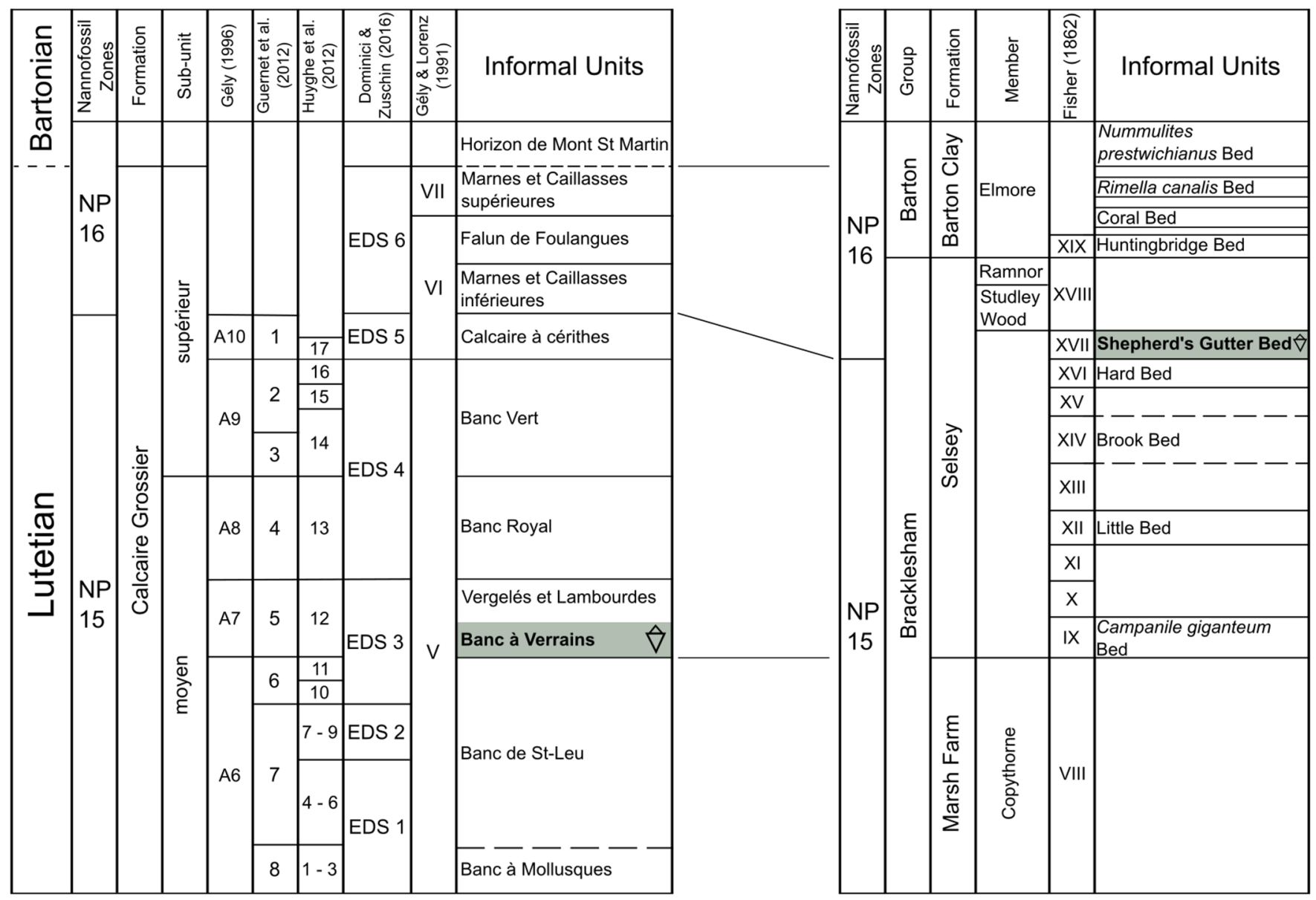

Fig. 2. Overview of the Lutetian stratigraphy of the Paris and Hampshire Basins. Paris Basin stratigraphy based on Merle (2008) and Dominici and Zuschin (2016), Hampshire Basin based on Whitecliff Bay stratigraphy from Melville and Freshney (1982) and King (2016), not to scale. The beds from which specimens are obtained are indicated in bold. The Paris Basin is estimated at 45-55 m thickness (Merle, 2008; King, 2016) and the Hampshire Basin at 115-120 m (Melville and Freshney, 1982; King, 2016).

corals (Paracyathus; Tracey et al., 1996; Barnet, 2021). The ostracod assemblage is largely similar between both basins (Guernet et al., 2012), suggesting fairly similar paleodepths and environmental conditions. The faunal assemblages and sedimentology of Bramshaw are interpreted as indicating a shallow sandy bottom at subtidal water depths of less than 20-30 m (Curry, 1965; Barnet, 2021).

\subsection{Studied specimens}

In this study, one specimen from Damery (DM1), two specimens from Fleury-la-Rivière (FL1 and FL2) and three specimens from Bramshaw (BR1, BR2 and BR3) are studied. Recently the genetic tree of Conidae has been reformulated whereby fossil genera fall within the large phylogenetic family of Conidae but have an unknown affiliation with extant genera (Tucker and Tenorio, 2009; Tracey et al., 2017). Therefore, while in previous studies fossil conids from these localities the specimens were designated as Conus (Tracey et al., 2017), here all studied specimens are designated within the Eoconus genus. The specimens from the Hampshire Basin (Bramshaw) are attributed to Eoconus edwardsi (Cossmann, 1889), the specimens from the Paris Basin (Damery and Fleury-laRivière) are attributed to Eoconus deperditus (Brugière, 1792).

Normal incident light photography reveals a difference in morphology and coloration between the specimens from the two basins (Fig. 3). The E. edwardsi specimens from the Hampshire Basin are all light to dark brown in color and all have a partially preserved protoconch. The largest specimen (BR1) is roughly $2.8 \mathrm{~cm}$ tall, specimen BR2 measured $2.2 \mathrm{~cm}$, and specimen BR3 $1.8 \mathrm{~cm}$. BR2 had a Paracyathus coral growth on its spire that was removed before sampling. The specimens from the Paris Basin are different in color, with a predominantly white to pinkish appearance, potentially highlighting a difference in preservation conditions. The E. deperditus specimen from Damery (DM1) is the largest from the Paris Basin, at $5.6 \mathrm{~cm}$, and lacks a preserved protoconch. The specimens from Fleury-la-Rivière are smaller, $5.2 \mathrm{~cm}$ for FL1 and $4.5 \mathrm{~cm}$ for FL2. FL1 shows slight signs of chemical weathering, with a dullish white appearance, and had two encrusting Cubitostrea oysters that were removed before sampling. 


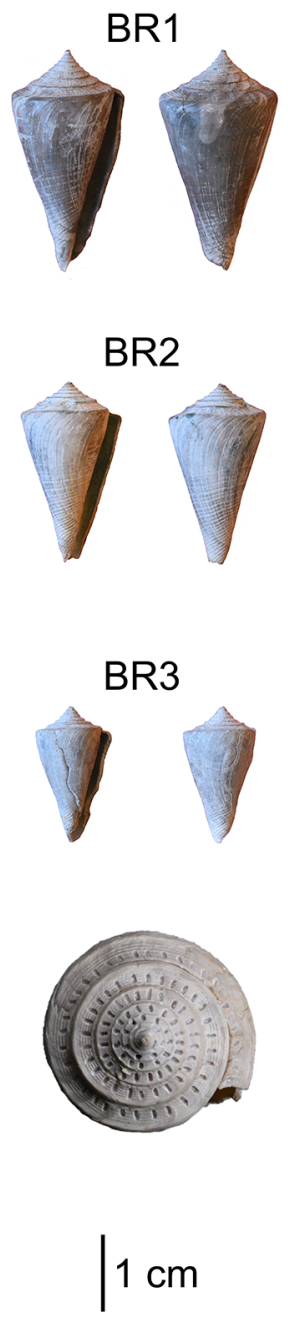

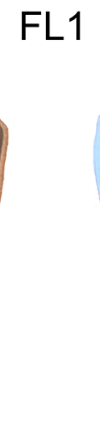

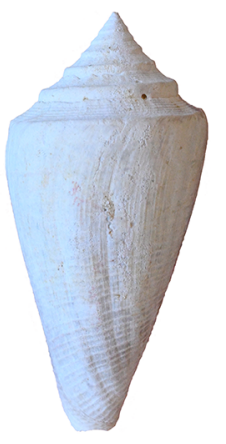

FL2
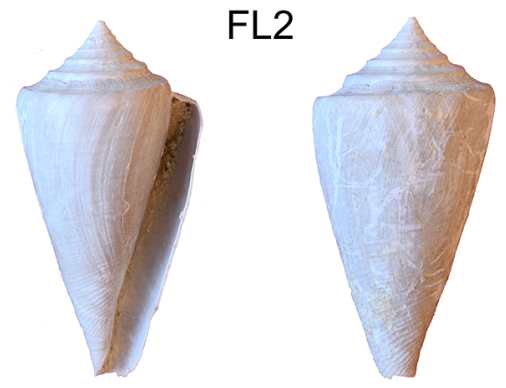

DM1
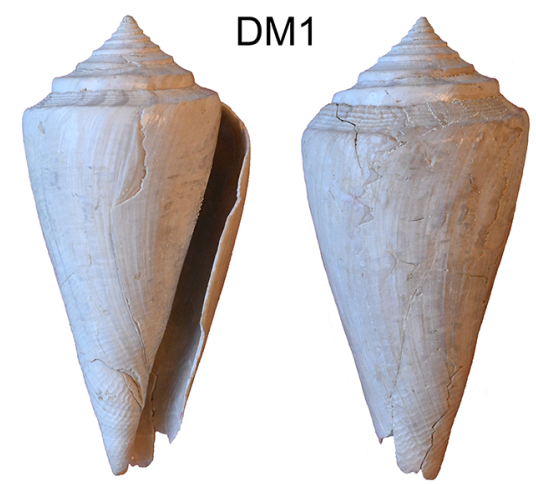

Fig. 3. Plate of the six used conid specimens, BR1, BR2 and BR3 are Eoconus edwardsi from Bramshaw, FL1 and FL2 from Fleury-laRivière and DM1 from Damery and are Eoconus deperditus. The top of specimen DM1 is shown, displaying the sample transect along the whorls.

\subsection{Preservation}

The middle Lutetian faunal assemblages of the Paris and Hampshire Basins have been noted for their well-preserved mollusk specimens, for example highlighted in Caze et al. (2011, 2012). Residual color patterns were visible under UV light and suggest an exquisite preservation. Further study by Purton (1997), Andreasson and Schmitz (2000), Huyghe et al. (2012a) and de Winter et al. (2020a) noted that primary aragonitic mineralogy is still present in mollusks from the studied localities. Cathodoluminescence, Scanning Electron Microscope (SEM) and optical microscopy confirms the pristine preservation for the used specimens, with only primary aragonite present (Fig. 4).

\section{Methodology}

\subsection{Stable isotope analyses}

Before sampling, the specimens were washed and ultrasonically cleaned to remove any residual sediment. Carbonate samples of $100-200 \mu \mathrm{g}$ aliquots were obtained using a $100 \mu \mathrm{m}$ Carbide tipped Dremel drill-bit, drilling at $1-2 \mathrm{~mm}$ intervals along the whorls, from shell apex to aperture (Fig. 3). The powdered samples were reacted with $104 \%$ phosphoric acid at $25^{\circ} \mathrm{C}$ and stable carbon $\left(\delta^{13} \mathrm{C}\right)$ and oxygen $\left(\delta^{18} \mathrm{O}\right)$ isotope ratios were measured in a Thermo Delta $\mathrm{V}$ Advantage isotope ratio mass spectrometer (IRMS) coupled to a Gasbench II. Measurement reproducibility was calculated using internal Merck and Fluka and certified L-SVEC and NBS-19 standards as references, calibrated to the V-PDB standard with a standard deviation of $\pm 0.15 \%$.

\subsection{Shell growth model}

Clear annual growth markings are lacking on the studied conids. Therefore, the data was coupled to a seasonal cycle by combining the seasonal variations recorded in the $\delta^{18} \mathrm{O}$ data to a sub-annual growth model as presented in Judd et al. (2018) and de Winter et al. (2020a). In this model, a chain of simulations is run combining sinusoids of the growth rate and sea water temperatures derived from the $\delta^{18} \mathrm{O}$ data. Through variation in the frequency, amplitude and phases, a best fit between the modelled and measured $\delta^{18} \mathrm{O}$ data are found. This is repeated until no better fit can be obtained. A difficulty inherent in this method is that the definition of a calendar year remains relatively arbitrary, while it has a significant impact on the model itself. Therefore, different definitions and timing of year markers, which encapsulate a calendar year, were tested and the values that best fit the data were taken.

\subsection{Paleotemperature and seawater oxygen isotope composition}

Most previous paleotemperature reconstruction studies on material from the Hampshire and Paris Basins assumed a constant, theoretical seawater oxygen isotope composition $\left(\delta^{18} \mathrm{O}_{\mathrm{sw}}\right)$ for neighboring localities and basins. However, the $\delta^{18} \mathrm{O}_{\text {sw }}$ value can vary between locations as for example shown in independent studies of the Eocene Paris and Hampshire Basins (Purton and Brasier, 1997; Andreasson and Schmitz, 2000), requiring another proxy to identify the potential difference. Theoretically, as the $\delta^{18} \mathrm{O}_{\text {carbonate }}$ is dependent on the temperature and $\delta^{18} \mathrm{O}_{\mathrm{sw}}$ as described in the empirically derived temperature-oxygen isotope fractionation relationship for aragonite, the $\delta^{18} \mathrm{O}_{\mathrm{sw}}$ value could be derived when the paleotemperature is known (Grossman and $\mathrm{Ku}, 1986$ ).

$$
\delta^{18} \mathrm{O}_{\mathrm{sw}}=\frac{\mathrm{T}-20.6}{4.34}+\delta^{18} \mathrm{O}_{\text {carbonate }} .
$$

In this study, a thought experiment is performed, in which the paleotemperature $(\mathrm{T})$ is assumed to be the same for both 


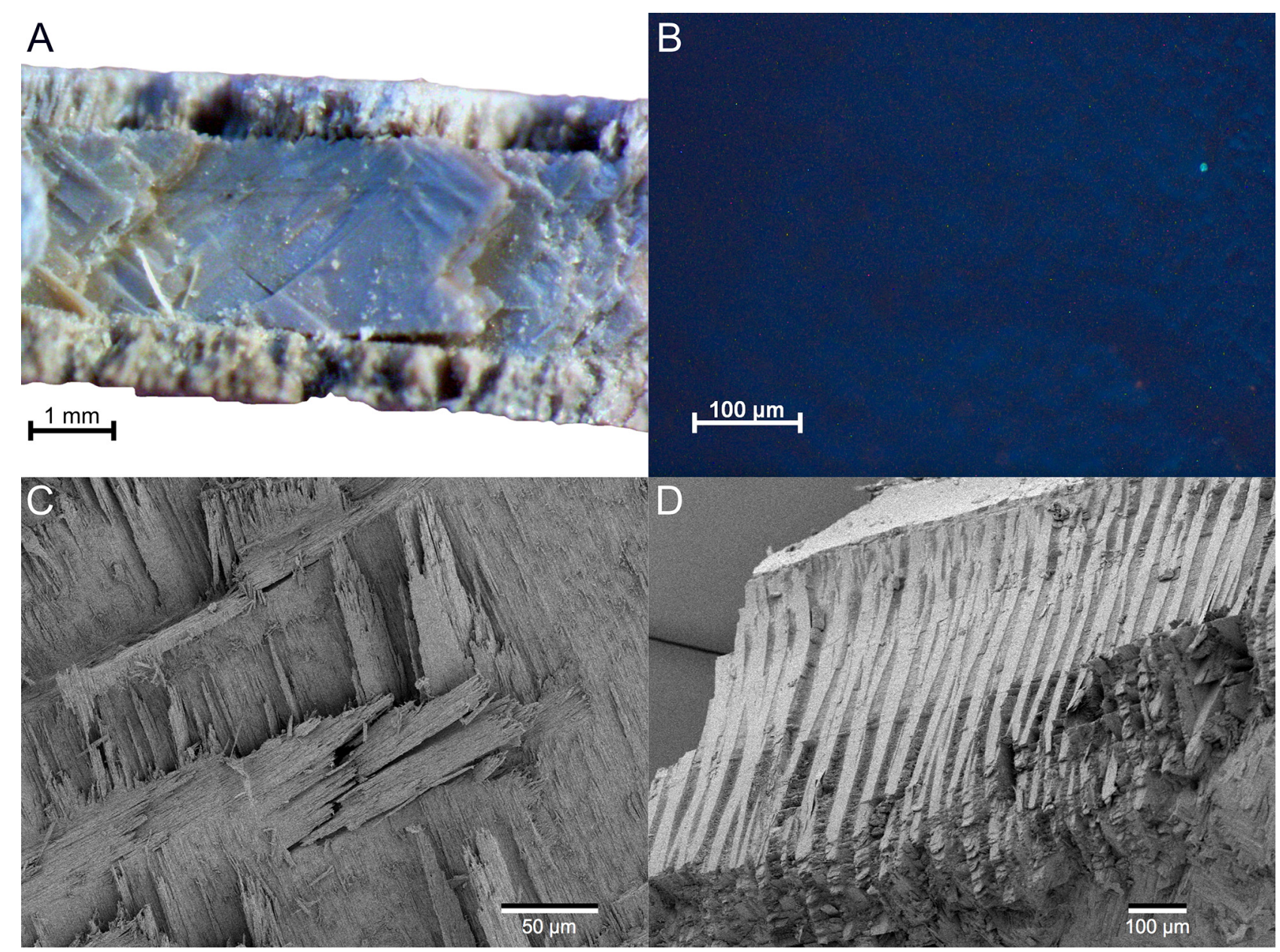

Fig. 4. (A) Optical microscopy of a cross-section through the shell of Eoconus edwardsi (BR1) with magnification 39x, showing well-preserved cross-laminar and prismatic aragonite crystals. (B) Cathodoluminescence microscopy of an internal cross-section through Eoconus deperditus (FL2), showing a faint dark blue luminescence indicative of preserved aragonite. (C, D) SEM microscopy of the cross-laminar aragonite crystals of Eoconus edwardsi (C), and Eoconus deperditus (D).

basins. Thus, any differences in measured $\delta^{18} \mathrm{O}_{\text {carbonate }}$ values between the specimens reflect differences in $\delta^{18} \mathrm{O}_{\mathrm{sw}}$. Comparing the reconstructed $\delta{ }^{18} \mathrm{O}_{\mathrm{sw}}$ of the specimens thus allows for the assessment of the difference between specimens or localities $\left(\Delta \delta^{18} \mathrm{O}_{\mathrm{sw}}\right)$ as seen in the formulae below. Hereby the $\delta^{18} \mathrm{O}_{\text {carbonate, }} \mathrm{A}$ and $\delta^{18} \mathrm{O}_{\text {carbonate }}, \mathrm{B}$ can be used for any specimen or location, such as the Paris or Hampshire Basins. A similar methodology was used by Schmitz and Andreasson (2001) and Latal et al. (2006) to obtain similar potential variations in the order of $\pm 1-2 \%$ in $\delta^{18} \mathrm{O}_{\mathrm{sw}}$ between neighboring regions.

$$
\begin{aligned}
& \Delta \delta^{18} \mathrm{O}_{\mathrm{sw}}=\left(\frac{\mathrm{T}-20.6}{4.34}+\delta^{18} \mathrm{O}_{\text {carbonate }}\right)_{\mathrm{A}} \\
&-\left(\frac{\mathrm{T}-20.6}{4.34}+\delta^{18} \mathrm{O}_{\text {carbonate }}\right)_{\mathrm{B}}, \\
& \frac{\mathrm{T}-20.6}{4.34 \mathrm{~A}}=\frac{\mathrm{T}-20.6}{4.34} \mathrm{~B} \\
& \therefore \Delta \delta^{18} \mathrm{O}_{\mathrm{sw}}=\delta^{18} \mathrm{O}_{\text {carbonate, } \mathrm{A}}-\delta^{18} \mathrm{O}_{\text {carbonate, } \mathrm{B} .}
\end{aligned}
$$

In previous studies, a $\delta^{18} \mathrm{O}_{\mathrm{sw}}$ value of $-0.75 \%$ has been used for other paleotemperature reconstructions for northern Europe. When corrected for latitudinal and climatic influences, this would give an assumed constant $\delta^{18} \mathrm{O}_{\mathrm{sw}}$ value of $-0.59 \%$ (Zachos et al., 1994; Huyghe et al., 2012a). However, the difference between specimens or localities $\left(\Delta \delta^{18} \mathrm{O}_{\mathrm{sw}}\right)$ is not dependent on this assumed initial $\delta^{18} \mathrm{O}_{\mathrm{sw}}$ or reconstructed temperatures and only reflects the differences between carbonate values from two specimens or locations, such as the Paris and Hampshire Basins. The aim of this thought experiment is to reconstruct $\Delta \delta^{18} \mathrm{O}_{\mathrm{sw}}$, not the paleotemperatures or absolute $\delta^{18} \mathrm{O}_{\mathrm{sw}}$ values.

\section{Results}

\subsection{Isotopes}

The $\delta^{13} \mathrm{C}$ and $\delta^{18} \mathrm{O}$ records show systematic fluctuations following the growth direction (Fig. 5). The $\delta^{18} \mathrm{O}$ records for the Hampshire Basin have distinctively more negative values than the Paris Basin, with average values between $-3.09 \%$ and $-1.30 \%$ and an average range of $1.70 \%$. The $\delta^{18} \mathrm{O}$ records 

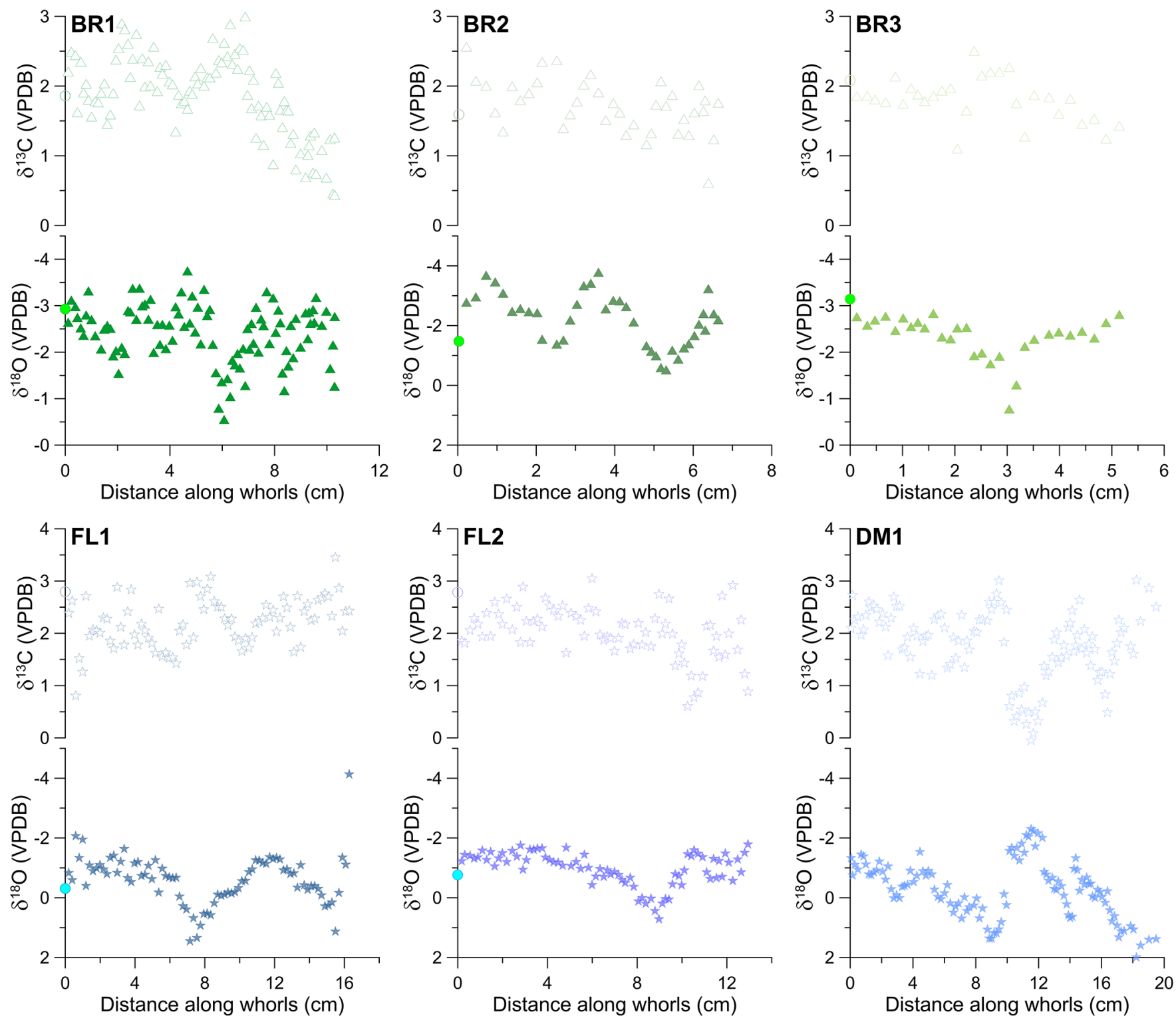

Fig. 5. Stable carbon and oxygen isotopes of the six specimens following its distance along the whorls. Measurements of the protoconch are given as a circle and a lighter shade of color, DM1 did not have a preserved protoconch.

from the Paris Basin in contrast have more positive values, with average values between $-1.68 \%$ and $0.35 \%$ and an average range of $1.99 \%$. The $\delta^{13} \mathrm{C}$ records for the Hampshire Basin have a narrower range relative to the Paris Basin, with average values between $1.80 \%$ and $1.91 \%$ and an average range of $0.28 \%$. The $\delta^{13} \mathrm{C}$ records from the Paris Basin in contrast have more positive values and fluctuate more, with average values between $1.88 \%$ and $2.36 \%$ and an average range of $0.72 \%$.

Wherever possible, the $\delta^{13} \mathrm{C}$ and $\delta^{18} \mathrm{O}$ values of the protoconch were also measured. This was possible for all specimens, except the one from Damery. The $\delta^{18} \mathrm{O}$ values of the protoconch are always roughly around the average $\delta^{18} \mathrm{O}$ value. Most of the protoconch values are above the values for the first summer except for BR3, which has the protoconch as its lowest initial value. These results suggest that during the Lutetian, spawning and hatching of conids likely happened during late spring, similar to modern day representatives of this family (Kohn, 1961).

\subsection{Shell growth model}

The growth model of Judd et al. (2018) was fitted to the obtained $\delta^{18} \mathrm{O}$ measurements and generally fit the data well $\left(\mathrm{R}^{2}>0.7\right)$, with $\mathrm{BR} 1$ as an outlier $\left(\mathrm{R}^{2}=0.45\right)$. Thus the model is valid for all other specimens to be used for the reconstruction of sub-annual growth rates. The model assumes daily incremental growth from which the daily growth rate can be extrapolated into calendar years (Fig. 6). Overall, the Paris Basin specimens have a higher daily growth rate, with maximum first year growth rates of $\sim 1.3 \mathrm{~mm} /$ day compared to maximum first year growth rates of $0.2-0.6 \mathrm{~mm} /$ day for the Hampshire Basin specimens. The timing and initiation of growth in the first year is comparable across both basins, 

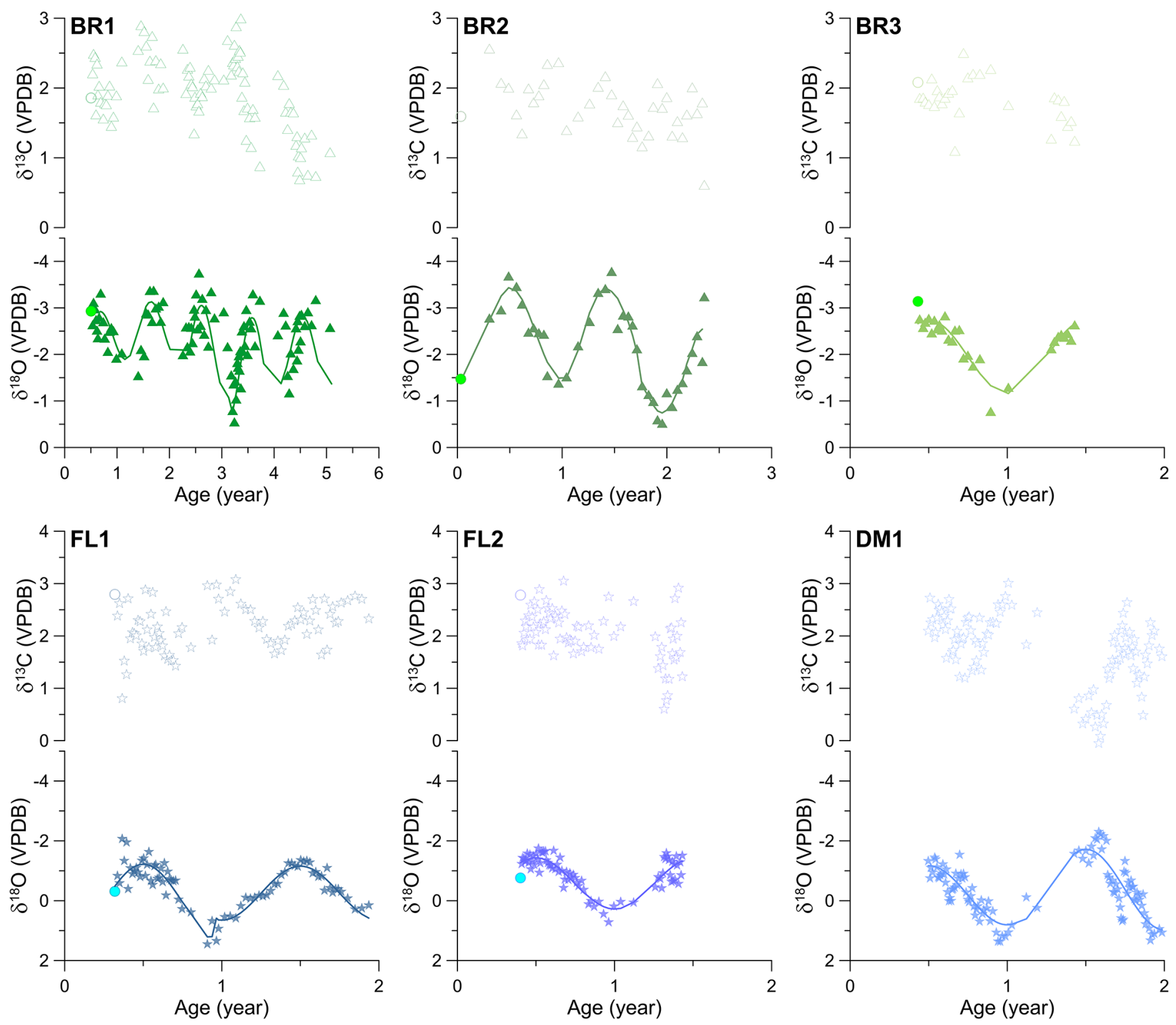

Fig. 6. Stable carbon and oxygen isotopes of the six specimens following a timescale with a modelled fit, following Judd et al. (2018). Measurements of the protoconch are given as a circle and a lighter shade of color, DM1 did not have a preserved protoconch.

occurring in the first half of the calendar year, with the exception of the BR2 specimen, which started growth in the beginning of the calendar year. Growth reductions occur at the same moment in the year for all specimens, ranging from the start to a quarter calendar year, representing the winter season.

The growth model calculates growth rates over a full calendar year, which allows for comparisons between specimens and basins during the entire year. On average the specimens from the Hampshire Basin had a growth rate of $\sim 50 \mathrm{~mm} /$ year in their first full year of growth, which then decreased by $\sim 66 \%$ into the second and third year. In contrast, the Paris Basin specimens had a growth rate of $\sim 160 \mathrm{~mm} /$ year in their first year, which decreased by $70 \%$ into the second year. Nevertheless, this apparent drop in growth rate is largely due to an incomplete second year of growth.

\section{Discussion}

\subsection{Isotopes}

Incrementally growing mollusks show sinusoidal trends in their measured $\delta^{18} \mathrm{O}$ values, with lower $\delta^{18} \mathrm{O}$ values during warmer months and higher $\delta^{18} \mathrm{O}$ values during colder months (Grossman and $\mathrm{Ku}, 1986$; Kobashi and Grossman, 2003). This is also observed in the conid specimens of this study (Fig. 5). The handful of previous studies on gastropods from the Paris and Hampshire Basins show similar $\delta^{18} \mathrm{O}$ values to those obtained here. In the Hampshire Basin, previously obtained $\delta^{18} \mathrm{O}$ values differ slightly from those found in this study, although this difference can largely be attributed to the known diversity of paleoenvironments between used localities within the basin and the difference in studied genus (Purton, 1997; Andreasson and Schmitz, 2000). In the Paris Basin the 

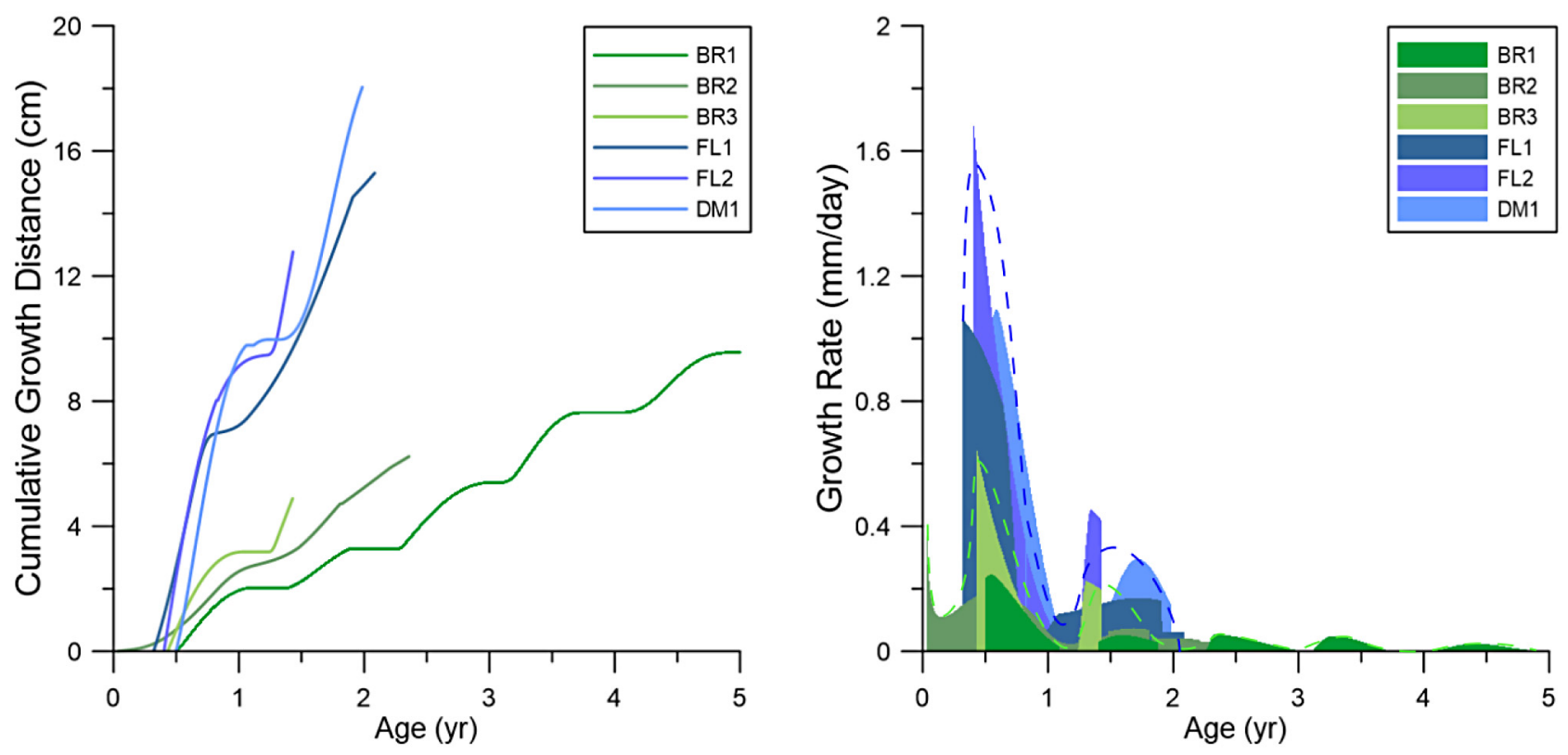

Fig. 7. (A) Cumulative growth distances in cm for each specimen against time, showing the difference between the Paris and Hampshire Basins. (B) Growth Rate in mm per day for each specimen against time, showing the similarity in timing of growth cessations and difference in maximum growth rate between the Paris and Hampshire Basins. Idealized growth rates, estimating the average growth rate per species, per basin shown as a colored (blue and green for the Paris and Hampshire Basins, respectively) dotted line.

obtained $\delta^{18} \mathrm{O}$ values are comparable to previous studies, with some variability due to differences in locality, depth and genus (Andreasson and Schmitz, 1996; Huyghe et al., 2012a, 2015).

\subsection{Growth rates}

The good fit of the growth model by Judd et al. (2018) to the obtained $\delta^{18} \mathrm{O}$ data shows that a large part of the sinusoidal trend is due to seasonal variability. These seasonal variabilities are mainly caused by fluctuations in the temperature and $\delta^{18} \mathrm{O}$ of the surrounding seawater $\left(\delta^{18} \mathrm{O}_{\mathrm{sw}}\right)$. Possible other effects on the incorporated $\delta^{18} \mathrm{O}$, including biological or physical effects, are negligible in conids (Sosdian et al., 2006; Lécuyer et al., 2012). Multiple studies have shown that mollusks, in particular gastropods, grow their shells at equilibrium with the surrounding seawater, especially with regard to oxygen isotopes (Krantz et al., 1987; Lécuyer et al., 2004, 2012), even for gastropods with much faster growth rates than those reported here (de Winter et al., 2020a). However, the model does not fit the obtained isotopic data perfectly. Variability can still be caused by analytical uncertainty and as such there are some jumps and mismatches. The arbitrary definition of the timing of a calendar year remains difficult, in particular in specimens BR1 and DM1, which contain large intra- and interannual fluctuations (Figs. 5 and 6). These intra-annual fluctuations possibly reflect relatively strong changes in living conditions throughout the year, such as intermittent periods of heavy rainfall and droughts. Nevertheless, when the most likely year markers are chosen, the growth allows for subannual and interbasinal comparisons in growth rates and interpretations in potential differing living conditions.

Average $\delta^{18} \mathrm{O}$ values per specimen do not give a fully representative view of the distribution of $\delta^{18} \mathrm{O}$ throughout the shell, with summer data relatively overrepresented (Fig. 5). Conids only grow during more favorable conditions. Stressful conditions, such as drought or extreme temperatures, result in slower growth and thus a biased distribution of stable isotope data throughout the year (Kobashi and Grossman, 2003; Gentry et al., 2008). This is especially likely in the middle Eocene, where the climate in northwest Europe was semi-arid, with strong seasonal variations in precipitation and temperature (Greenwood and Wing, 1995; Collinson, 2000; de Winter et al., 2020a). The winter cold likely causes a full growth cessation, which is seen in most specimens (Fig. 7). The Hampshire Basin specimens reach maximum daily ( $\sim 0.4 \mathrm{~mm} /$ day) and annual $(\sim 50 \mathrm{~mm} /$ year) growth rates similar to modern conid species (Frank, 1969; Kobashi and Grossman, 2003; Sosdian et al., 2006). The daily (1.3 mm/day) and annual $(160 \mathrm{~mm} / \mathrm{year})$ growth rates reached by the Paris Basin specimens far exceed those of modern conids and potentially highlight the exceptionally favorable growth conditions of the Paris Basin, as also found by Dominici and Zuschin (2016) and de Winter et al. (2020a). Similar high growth rates of $\sim 40 \mathrm{~mm} /$ year have also been found in mollusks that lived in central Europe during the warm Miocene Climatic Optimum (14.8-14.5 Ma; Harzhauser et al., 2011). Perhaps it is no coincidence that the giant gastropod Campanile giganteum (Lamarck, 1804), which has the highest growth rates known among mollusks to date (de Winter et al., 2020a), occurs in the same beds as our studied conid specimens.

\subsection{Carbon}

The $\delta^{13} \mathrm{C}$ of mollusk shells is often used in studies as an indicator of ambient carbon input and primary productivity, as well as the effect of ecology and feeding habit (Purton and 


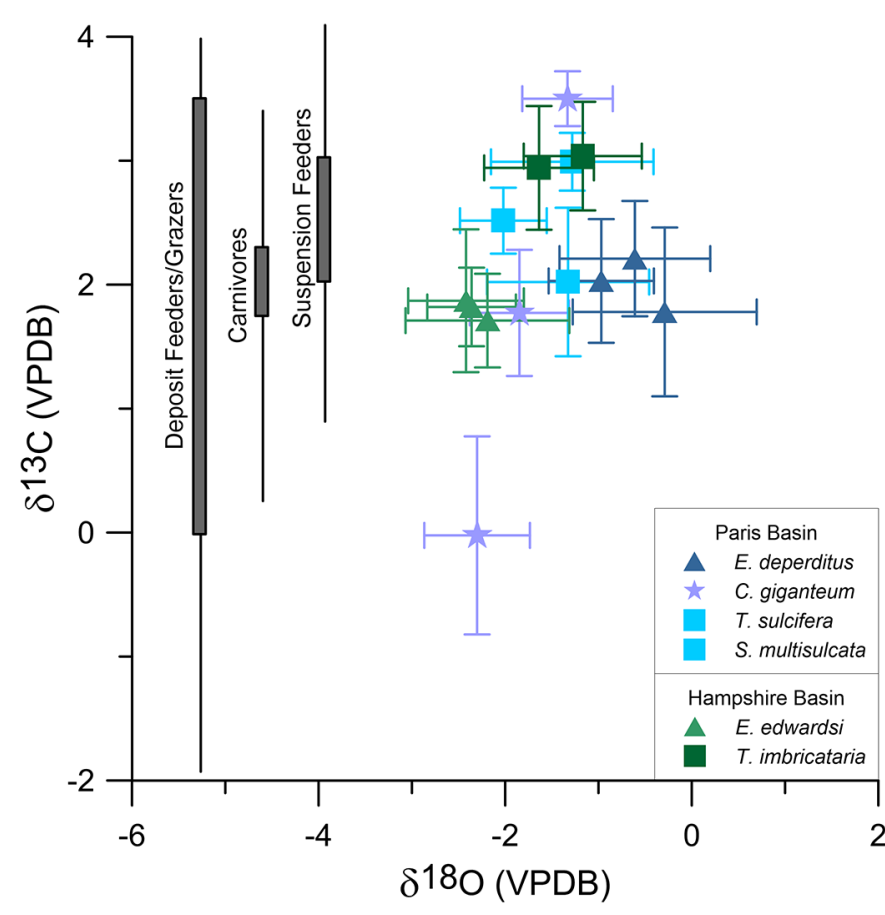

Fig. 8. Stable oxygen and carbon isotope cross plots of gastropods from this study and other studies from the Paris and Hampshire Basins, in blue and green shades, respectively. Suspension feeders Turritella sulcifera (Andreasson and Schmitz, 1996), Turritella imbricataria (Andreasson and Schmitz, 2000) and Sigmesalia multisulcata (Huyghe et al., 2012a) are shown as squares, carnivores Eoconus edwardsi (this study) and Eoconus deperditus (this study) as triangles and deposit feeders/grazers Campanile giganteum (de Winter et al., 2020a) as stars, with standard deviation as horizontal and vertical bars. Vertical bars show total range of $\delta^{13} \mathrm{C}$ for suspension feeders, carnivores and deposit feeders/grazers, with thicker bars showing the ranges of averages.

Brasier, 1997; Vander Zanden and Rasmussen, 2001; Latal et al., 2006; McConnaughey and Gillikin, 2008). The timing of $\delta^{13} \mathrm{C}$ and $\delta^{18} \mathrm{O}$ variations can be of interest. The timing of each data-point in a calendar year was done through the growth model and can be used to pinpoint approximate seasons in which fluctuations and extremes of $\delta^{13} \mathrm{C}$ and $\delta^{18} \mathrm{O}$ occur. Similar to previous studies on Lutetian mollusks (de Winter et al., 2020a), the carbon isotope records of the studied conids do not show clear seasonal signals. There is a large variability within seasons and no consistent pattern between the studied specimens. Hence, the $\delta^{13} \mathrm{C}$ fluctuations do not appear to be related to annual, seasonal environmental changes, but instead are more likely heavily influenced by vital effects.

With comparisons to other studies from the same basins and time period, a grouping of ecological guilds can be made along low to high $\delta^{13} \mathrm{C}$ values. Three guilds can generally be distinguished as seen in Figure 8; suspension feeders such as turritellids have the highest $\delta{ }^{13} \mathrm{C}$ values (4\%o-1\%o), carnivorous taxa such as conids have moderate $\delta^{13} \mathrm{C}$ values (3\%o-0\%o) and deposit feeders/grazers such as campanilids have the lowest average $\delta{ }^{13} \mathrm{C}$ values and widest range (4\%o to $-2 \%$ ). The same pattern emerges for turritellids and carnivores from the Eocene Gulf Coast along the Gulf of Mexico and Miocene
Central Paratethys (Kobashi et al., 2004; Latal et al., 2006). The suspension feeders generally have higher $\delta^{13} \mathrm{C}$ values and the deposit feeders/grazers have a large range but occupy lower $\delta{ }^{13} \mathrm{C}$ values. Studies on modern benthic fauna also show this difference in range in carbon isotope signals between the different ecological guilds, with a larger range for deposit feeders and grazers than the suspension feeders and carnivores, which is likely caused by differences in $\delta^{13} \mathrm{C}$ of the consumed diet and the position in the food web (Doi et al., 2005; Carlier et al., 2007).

\subsection{Seasonality}

The average seasonal ranges in $\delta^{18} \mathrm{O}$ are fairly similar in both basins (1.99\%o and $1.70 \%$ for the Paris and Hampshire Basins, respectively), as might be expected for geographically close, connected basins (Purton and Brasier, 1997; Andreasson and Schmitz, 2000; Huyghe et al., 2015; de Winter et al., 2020a). This reconstructed temperature seasonality is slightly lower than previously obtained paleoseasonality for these basins of 2.00-2.50\% for both the Paris and Hampshire Basins (Andreasson and Schmitz, 2000; Huyghe et al., 2015; de Winter et al., 2020a), which might be related to growth cessations and/or different living depths due to the difference in mollusks used between these studies. The paleodepth differences between Bramshaw, Fleury-la-Rivière and Damery could explain the slight differences in seasonal range between the sites $(1.70 \%$ v v. $1.99 \%$ o), with slightly greater depths at Bramshaw experiencing lower seasonal effects and range than at Fleury-la-Rivière and Damery (Purton, 1997; Kobashi et al., 2004).

Remarkably, the Hampshire Basin generally has considerably lower $\delta^{18} \mathrm{O}_{\text {carbonate values than the Paris Basin. Possible }}$ explanations for a more depleted $\delta^{18} \mathrm{O}_{\text {carbonate }}$ signal are significantly higher temperatures, up to $8{ }^{\circ} \mathrm{C}$ which we consider unlikely due to the proximity of the basins, or higher freshwater influxes in the Hampshire Basin. A minor part of the difference in $\delta^{18} \mathrm{O}_{\text {carbonate values between the basins could }}$ also be attributed to a difference in habitat and paleodepth between the studied sites. Most conids are known to strongly prefer sheltered "refuges" and especially thrive in the presence of algae, seagrass, coral debris and other substrates that provide additional microhabitats and debris (Kohn, 1959; Kohn, 1968; Leviten and Kohn, 1980), which could lead to slightly different temperatures on the sea floor. While the paleodepth might also be slightly different between the localities, this cannot easily explain the lower $\delta^{18} \mathrm{O}_{\text {carbonate }}$ values at Bramshaw, compared to Fleury-la-Rivière and Damery. The Fleury-la-Rivière and Damery sites were likely characterized by paleodepths of 5-20 m, while Bramshaw is estimated to have been situated in a slightly deeper setting, with paleodepths of up to $20-30 \mathrm{~m}$. This difference in paleodepth would likely result in slightly cooler bottom

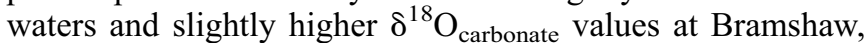
the opposite of the observed difference. Therefore, the difference in $\delta^{18} \mathrm{O}_{\text {carbonate values between Bramshaw and }}$ Fleury-la-Rivière and Damery are considered to mainly reflect higher freshwater influxes in the Hampshire Basin, compared to the Paris Basin, rather than any differences in habitat or paleodepth. 


\subsection{Calculated $\delta^{18} \mathrm{O}_{\mathrm{sw}}$ difference between basins}

The difference in absolute $\delta^{18} \mathrm{O}_{\text {carbonate }}$ values between two neighboring basins is substantial.

Given that the sea water temperatures are assumed to have been similar between the sites, this results in an average difference in $\delta^{18} \mathrm{O}_{\mathrm{sw}}\left(\Delta \delta^{18} \mathrm{O}_{\mathrm{sw}}\right)$ between the Paris and Hampshire basins of approximately $-1.80 \%$ (Fig. 9). This $\Delta \delta^{18} \mathrm{O}_{\mathrm{sw}}$ is remarkable, considering the close proximity between these basins and their connection to the English Channel. Even with a correction for the $2^{\circ}$ latitudinal difference between the localities of the two basins, there would only be a difference in $\delta 180$ sw value of 0.09 between the basins (Butterlin et al., 1993). We nevertheless consider such differences between the Paris and Hampshire Basins plausible, as there are ample examples of modern-day basins at the same latitudes, with similar $\delta^{18} \mathrm{O}_{\mathrm{sw}}$ differences of $\pm 2 \%$ o over relatively short distances, for example along the Adriatic coastline (Kanduč et al., 2011). Our results therefore suggest a systematic offset in $\delta^{18} \mathrm{O}_{\text {sw }}$ between the Paris and Hampshire Basins. The more enclosed Hampshire Basin has a pronounced lower $\delta^{18} \mathrm{O}_{\mathrm{sw}}$ value, suggesting a larger fluvial input, which is in line with the extensive fluvial and estuarine deposits around the edges of the basin (Murray and Wright, 1974; Plint, 1982, 1988; Gibbard and Lewin, 2003). Moreover, the fluvial input was probably retained longer within the basin due to its enclosed geographical setting. A lower runoff and slightly more evaporative setting, consistent with the evaporative lacustrine deposits at the southern edges of the basin, are suggested for the more open Paris Basin (Tivollier et al., 1968; Thiry, 1989; Huyghe et al., 2012a). Interestingly, one of the studied individuals from the Paris Basin, FL1, has a sudden decrease in $\delta^{18} \mathrm{O}$ in its last growth increments. We tentatively speculate that this could suggest that this individual animal could have died from a short-lived intense precipitation event, pushing the ambient sea water salinity below the salinity tolerance of this species, as has been observed in modern conids (Leviten and Kohn, 1980).

Within the Paris Basin, there is a difference of up to $0.55 \%$ between neighboring localities, whereby the Damery specimen shows a higher $\delta^{18} \mathrm{O}_{\mathrm{sw}}$ relative to the Fleury-la-Rivière specimens. In order to obtain a $\delta^{18} \mathrm{O}_{\mathrm{sw}}$ difference of the same magnitude a temperature difference of $2.39^{\circ} \mathrm{C}$ would be needed, which we consider to be highly unlikely between such close localities. As the two localities are only a few km apart, a more likely explanation could be a more restricted setting with less fluvial influence or a stronger influence from neighboring high saline lagunes at the Damery locality. Similar differences in paleoenvironment have been found in the area around Grignon on the other side of the Paris Basin (Guernet et al., 2012; Huyghe et al., 2015; Sanders et al., 2015).

\subsection{Potential seasonal variability in $\delta^{18} O_{s w}$}

Using techniques that are independent of variations in $\delta^{18} \mathrm{O}_{\mathrm{sw}}$, such as paleobotany and $\mathrm{Mg} / \mathrm{Ca}$ on large benthic foraminifera, previous studies reconstructed a temperature paleoseasonality in the range of $5-9^{\circ} \mathrm{C}$ for northwest Europe (Mosbrugger et al., 2005; Evans et al., 2018). When calculated back to $\delta^{18} \mathrm{O}$, this reconstructed seasonality would represent a

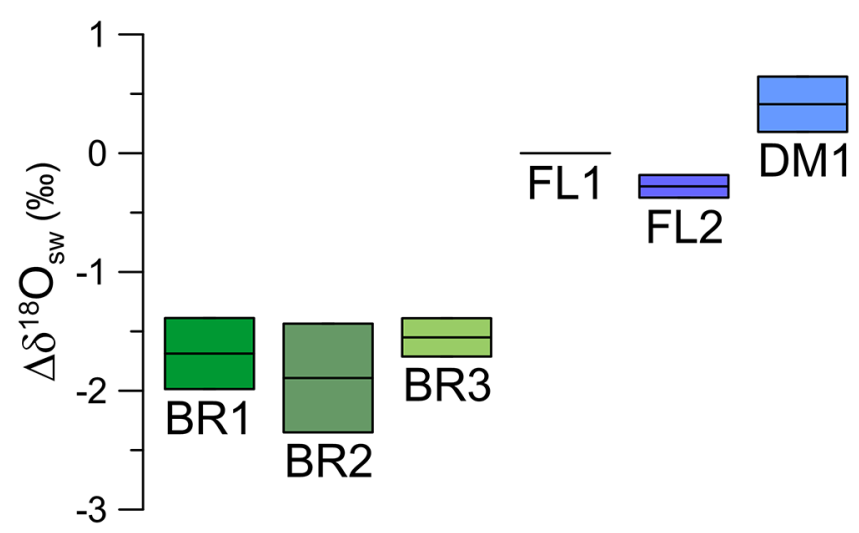

Fig. 9. Calculated $\Delta \delta^{18} \mathrm{O}_{\mathrm{sw}}$ values of the Paris and Hampshire Basins using a theoretical paleotemperature of $16-24^{\circ} \mathrm{C}$.

range of $1.2-2.0 \% \delta^{18} \mathrm{O}_{\text {carbonate }}$ throughout the year. Hence, the seasonal range of $1.70-1.99 \%$ recorded in this study could largely be caused by temperature seasonality. Nonetheless, the initial assumption that the $\delta^{18} \mathrm{O}_{\mathrm{sw}}$ is constant throughout the year, as is assumed in most paleotemperature reconstruction studies, is most likely false. It is expected that $\delta^{18} \mathrm{O}_{\mathrm{sw}}$ fluctuated considerably throughout the year, as noted in a range of modern settings (Schmitz and Andreasson, 2001; Swart and Price, 2002; Tao et al., 2013). While not included in this study, modelling and isotopic studies focusing on the paleohydrology during the Eocene could give insights into what the conids possibly experienced in terms of seasonal $\delta^{18} \mathrm{O}_{\mathrm{sw}}$ variability and provide additional insights into the regional seasonal paleohydrology during the Lutetian (Huber and Goldner, 2012; Huyghe et al., 2012b). No seasonal $\delta^{18} \mathrm{O}_{\mathrm{sw}}$ studies have been previously performed specifically on the Lutetian Paris and Hampshire Basins.

In the present day, European winter months are characterized by an increase in overall freshwater input into its basins, caused by enhanced precipitation and subsequent fluvial influxes (Bouwer et al., 2006). Atmospheric modelling shows the same occurring during the Eocene (Huber and Goldner, 2012). Semi-arid, para-tropical climates, such as during the Lutetian in northwest Europe, are particularly characterized by strong differentiations between a rainy and dry season (Tao et al., 2013). During the rainy season, there is an increase in the amount and intensity of precipitation events, depositing generally low $\delta^{18} \mathrm{O}$ into the water column (Purton and Brasier, 1997). Also, for the more continental setting of middle Eocene central Germany, distinct dry and wet seasons have been inferred, with mild, wet, frost-free winters (Pomerol, 1973; Greenwood and Wing, 1995; Collinson, 2000). Thus, a dry summer and wet winter are expected for the Lutetian Paris and Hampshire Basins. Freshwater has a relatively low $\delta^{18} \mathrm{O}_{\text {sw }}$ value relative to marine waters (Comas-Bru et al., 2016). Prolonged periods of frequent storm events show a sustained decrease in $\delta^{18} \mathrm{O}_{\mathrm{sw}}$ of $1-4 \%$ in modern day tropical climates in a range of different settings, from sheltered bays to open shelf environments (Drupp et al., 2011; Tao et al., 2013; Lambs et al., 2018). Therefore, during the Eocene winter months in northwest Europe, the $\delta^{18} \mathrm{O}_{\mathrm{sw}}$ was likely depleted due to enhanced freshwater input. The $\delta^{18} \mathrm{O}_{\mathrm{sw}}$ values would then be higher during the summer and lower during the winter seasons, 
respectively. This is in contrast to the temperature effect on $\delta^{18} \mathrm{O}_{\text {carbonate, }}$ which increases with decreasing temperature (Grossman and $\mathrm{Ku}, 1986$ ).

This study highlights the influence of assumed $\delta^{18} \mathrm{O}_{\mathrm{sw}}$ values in stable isotope-based paleoclimate studies. We show that further studies to fully constrain the Lutetian paleotemperature and $\delta^{18} \mathrm{O}_{\mathrm{sw}}$ are pivotal. The best approach would be to use a fully independent temperature proxy, such as clumped isotopes (Eiler, 2011). This proxy could show how variable the $\delta^{18} \mathrm{O}_{\mathrm{sw}}$ is throughout the year and give an indication on the absolute difference in $\delta^{18} \mathrm{O}_{\text {sw }}$ between basins, as for example illustrated in a clumped isotope study on Cretaceous bivalves (de Winter et al., 2020b). In addition, trace-elemental ratios, such as $\mathrm{Sr} / \mathrm{Ca}$ and $\mathrm{Mg} / \mathrm{Ca}$, have also been previously used on conids to reconstruct a salinityindependent paleotemperature- $\delta{ }^{18} \mathrm{O}$ relationship (Sosdian et al., 2006; Gentry et al., 2008; Tao and Grossman, 2010). However, large variabilities in this relationship between the trace-elemental ratios and temperature emerged between different species and even for specimens within the same species (Gentry et al., 2008). This variability was likely caused by vital effects, varying influence of growth and metabolic rates and species-specific physiologies (Gentry et al., 2008; Irie and Suzuki, 2020). Moreover, the relationship between temperature and trace elemental ratios such as $\mathrm{Sr} / \mathrm{Ca}$ and $\mathrm{Mg} / \mathrm{Ca}$ is also influenced by the $\mathrm{Sr} / \mathrm{Ca}$ and $\mathrm{Mg} / \mathrm{Ca}$ values of the ambient sea water (Freitas et al., 2006; Poulain et al., 2015; Lebrato et al., 2020), a parameter that is notoriously difficult to constrain for deep time settings (Purton, 1997; Purton et al., 1999; Tao and Grossman, 2010; Irie and Suzuki, 2020). Therefore, while potentially useful for specimens of extant species living in relatively modern marine settings, applying trace-elemental ratios such as $\mathrm{Sr} / \mathrm{Ca}$ and $\mathrm{Mg} / \mathrm{Ca}$ as a paleothermometer on fossil specimens from deep time is considered problematic.

Apart from this, to fully grasp the paleoclimate and weather patterns in the Lutetian greenhouse world, the resolution of paleoseasonality studies would also need to be increased. In tropical regions precipitation is often characterized by brief (hourly to daily) and intense storm events, a resolution the conids in this study cannot provide. Sub-daily sampling on very fast growing mollusks, such as campanilids (de Winter et al., 2020a), could potentially show individual storm or river influx events (Van Horebeek et al., 2021).

\section{Conclusions}

The seasonal hydrological conditions of two Eocene sites in northwest Europe were reconstructed through the comparison of Lutetian mollusk $\delta^{18} \mathrm{O}$ records from the Paris and Hampshire Basins. Both basins showed favorable growth conditions for conids, with growth rates equal to and above growth rates of modern day conids. While the average seasonal range in $\delta^{18} \mathrm{O}$ was fairly similar between the basins, the $\delta^{18} \mathrm{O}$ values for the Hampshire Basin are consistently below those for the Paris Basin, suggesting a regional difference in $\delta^{18} \mathrm{O}_{\mathrm{sw}}$ of about $2 \%$. We infer that this difference resulted from extensive fluvial input into the more enclosed Hampshire Basin and more evaporative conditions on the studied margin of the Paris Basin. This study shows the importance of incorporating paleohydrological conditions in stable isotopebased paleotemperature reconstructions, highlighting the need for caution in assuming a constant, open ocean $\delta^{18} \mathrm{O}_{\mathrm{sw}}$ for shallow marine basins.

\section{Supplementary Material}

Supporting Material. Isotopic and model data.

The Supplementary Material is available at http://www.bsgf.fr/ $10.1051 / \mathrm{bsgf} / 2022002 / \mathrm{olm}$.

\section{Authors' contributions}

JV and AJC conceived the study; AJC generated and interpreted the isotope data and JV assisted in analysis and interpretation. All authors contributed to writing the manuscript. The analyses were supported by KU Leuven funds to RPS. All authors approved the final manuscript.

\section{Funding}

JV is funded by the Research Foundation Flanders (FWO Grant $12 \mathrm{Z} 6618 \mathrm{~N})$.

\section{Availability of data and materials}

All data generated or analysed during this study are included in this published article and its supplementary information files.

\section{Authors' information}

This study was performed as part of the graduate research of AJC.

Acknowledgements. The authors would like to thank Z. Kelemen and S. Bouillon for their helpful comments and guidance with the IRMS analyses and M. Doubrawa for assistance with the SEM microscope. The authors would also like to thank O. Namur for help with the French translation and P. Stassen for field assistance. We thank G. Paris and one anonymous reviewer for their helpful comments and suggestions.

\section{References}

Andreasson FP, Schmitz B. 1996. Winter and summer temperatures of the early middle Eocene of France from Turritella $\delta^{18} \mathrm{O}$ profiles. Geology 24: 1067-70. https://doi.org/10.1130/0091-7613(1997) $025<0957$ :WASTOT $>2.3$.CO;2.

Andreasson FP, Schmitz B. 2000. Temperature seasonality in the early middle Eocene North Atlantic region: evidence from stable isotope profiles of marine gastropod shells. Bulletin of the Geological Society of America 112: 628-40. https://doi.org/10.1130/ 0016-7606(2000)112<628:TSITEM > 2.0.CO;2.

Barnet J. 2021. New forest: Geology and fossils, 1st ed. Ramsbury: The Crowood Press.

Barron JA, Stickley CE, Bukry D. 2015. Paleoceanographic, and paleoclimatic constraints on the global Eocene diatom and 
silicoflagellate record. Palaeogeography, Palaeoclimatology, Palaeoecology 422: 85-100. https://doi.org/10.1016/j. palaeo.2015.01.015.

Boulter MC, Hubbard RNLB. 1982. Objective paleoecological and biostratigraphic interpretation of Tertiary palynological data by multivariate statistical analysis. Palynology 6: 55-68. https://doi. org/10.1080/01916122.1982.9989234.

Bouwer LM, Vermaat JE, Aerts JCJH. 2006. Winter atmospheric circulation and river discharge in northwest Europe. Geophysical Research Letters 33: 2-5. https://doi.org/10.1029/2005GL025548.

Brugière J-G. 1792. Encyclopédie méthodique ou par orde de matières. Histoire naturelle des vers. Tome Premier. Paris : Panckoucke.

Butterlin J, Vrielynck B, Bignot G, Clermonte J, Colchen M, Dercourt J, et al. 1993. Lutetian (46 to $40 \mathrm{Ma}$ ). In: Dercourt J, Ricou LE, Vrielynck B, eds. Atlas Tethys Palaeoenvironmental Maps. Explanatory Notes, pp. 197-209.

Carlier A, Riera P, Amouroux JM, Bodiou JY, Grémare A. 2007. Benthic trophic network in the Bay of Banyuls-Sur-Mer (northwest Mediterranean, France): an assessment based on stable carbon and nitrogen isotopes analysis. Estuarine, Coastal and Shelf Science 72: 1-15. https://doi.org/10.1016/j.ecss.2006.10.001.

Caze B, Merle D, Saint Martin J-P, Pacaud J-M. 2011. Apport des motifs colorés résiduels dans la caractérisation des espèces de mollusques Cénozoïques (Gastropoda, Bivalvia). Comptes Rendus-Palevol 10: 171-79. https://doi.org/10.1016/j. crpv.2010.10.005.

Caze B, Merle D, Saint Martin J-P, Pacaud J-M. 2012. Les mollusques Éocènes se dévoilent sous ultraviolets. In: Lebrun P, ed. Les coquillages de l'Eocène du bassin Parisien, pp. 15-56.

Collinson ME. 1996. Plant macrofossils from the Bracklesham Group (Early and Middle Eocene), Bracklesham Bay, West Sussex, England: review and significance in the context of coeval british Tertiary floras. Tertiary Research 16: 175-202.

Collinson ME. 2000. Cenozoic evolution of modern plant communities and vegetation. In: Culver SJ, Rawson PF, eds. Biotic response to global change, pp.223-243. https://doi.org/10.1017/ CBO9780511535505.017.

Collinson ME, Hooker JJ. 2003. Paleogene vegetation of Eurasia: Framework for mammalian faunas. Deinsea 10: 41-84.

Comas-Bru L, McDermott F, Werner M. 2016. The effect of the east Atlantic pattern on the precipitation $\delta^{18} \mathrm{O}-\mathrm{NAO}$ relationship in Europe. Climate Dynamics 47: 2059-2069. https://doi.org/ 10.1007/s00382-015-2950-1.

Cossmann M. 1889. Catalogue illustré des coquilles fossiles de l'Éocène des environs de Paris. Annales de la Société royale malacologique de Belgique, 1-385.

Curry D. 1965. The Palaeogene beds of south-east England. Proceedings of the Geologists' Association 76: 151-173.

Daley B. 1972. Some problems concerning the early Tertiary climate of southern Britain. Palaeogeography, Palaeoclimatology, Palaeoecology 11: 177-90.

de Winter NJ, Vellekoop J, Clark AJ, Stassen P, Speijer RP, Claeys P. 2020a. The giant marine gastropod Campanile Giganteum (Lamarck, 1804) as a high-resolution archive of seasonality in the Eocene greenhouse world. Geochemistry, Geophysics, Geosystems, 0-2. https://doi.org/10.1029/2019gc008794.

de Winter NJ, Müller I, Kocken I, Thibault N, Ullmann CV, Farnsworth A, et al. 2020b. First absolute seasonal temperature estimates for greenhouse climate from clumped isotopes in bivalve shells. https://doi.org/10.21203/rs.3.rs-39203/v1.

Doi H, Matsumasa M, Toya T, Satoh N, Mizota C, Maki Y, et al. 2005. Spatial shifts in food sources for macrozoobenthos in an estuarine ecosystem: carbon and nitrogen stable isotope analyses. Estuarine,
Coastal and Shelf Science 64: 316-22. https://doi.org/10.1016/j. ecss.2005.02.028.

Dominici S, Zuschin M. 2016. Palaeocommunities, diversity and sealevel change from middle Eocene shell beds of the Paris Basin. Journal of the Geological Society 173: 889-900. https://doi.org/ 10.1144/jgs2015-150.

Drupp P, de Carlo EH, Mackenzie FT, Bienfang P, Sabine CL. 2011. Nutrient inputs, phytoplankton response, and $\mathrm{CO}_{2}$ variations in a semi-enclosed subtropical embayment, Kaneohe Bay, Hawaii. Aquatic Geochemistry 17: 473-98. https://doi.org/10.1007/ s10498-010-9115-y.

Dugué O, Auffret J-P, Poupinet N. 2007. Cenozoic shelly sands in the Cotentin (Armorican Massif, Normandy, France): a record of Atlantic transgressions and intraplate Cenozoic deformations. Comptes Rendus-Geoscience 339: 110-20. https://doi.org/ 10.1016/j.crte.2007.01.001.

Eiler JM. 2011. Paleoclimate reconstruction using carbonate clumped isotope thermometry. Quaternary Science Reviews 30: 3575-88. https://doi.org/10.1016/j.quascirev.2011.09.001.

Evans D, Sagoo N, Renema W, Cotton LJ, Müller W, Todd JA, et al. 2018. Eocene greenhouse climate revealed by coupled clumped isotope- $\mathrm{Mg} / \mathrm{Ca}$ thermometry. Proceedings of the National Academy of Sciences 115: 1174-1179. https://doi.org/10.1073/ pnas. 1714744115 .

Frank PW. 1969. Growth rates and longevity of some gastropod mollusks on the coral reef at Heron Island. Oecologia 2: 232-50. https://doi.org/10.1007/BF00379161.

Freitas PS, Clarke LJ, Kennedy H, Richardson CA, Abrantes F. 2006. Environmental and biological controls on elemental $(\mathrm{Mg} / \mathrm{Ca}, \mathrm{Sr} / \mathrm{Ca}$ and $\mathrm{Mn} / \mathrm{Ca}$ ) ratios in shells of the king scallop Pecten maximus. Geochimica et Cosmochimica Acta 70: 5119-5133. https://doi.org/ 10.1016/j.gca.2006.07.029.

Gat JR. 2010. Isotope hydrology: a study of the water cycle, 1st ed. London: Imperial College Press.

Gentry DK, Sosdian S, Grossman EL, Rosenthal Y, Hicks D, Lear CH. 2008. Stable isotope and $\mathrm{Sr} / \mathrm{Ca}$ profiles from the marine gastropod Conus ermineus: testing a multiproxy approach for inferring paleotemperature and paleosalinity. Palaios 23: 195-209. https://doi.org/10.2110/palo.2006.p06-112r.

Gibbard PL, Lewin J. 2003. The history of the major rivers of southern Britain during the Tertiary. Journal of the Geological Society 160: 829-46. https://doi.org/10.1144/0016-764902-137.

Goikoetxea N, Borja Á, Fontán A, González M, Valencia V. 2009. Trends and anomalies in sea-surface temperature, observed over the last 60 years, within the southeastern Bay of Biscay. Continental Shelf Research 29: 1060-69. https://doi.org/10.1016/ j.csr2008.11.014.

Greenwood DR, Wing SL. 1995. Eocene continental climates and latitudinal temperature gradients. Geology 23: 1044-48. https://doi. org/10.1130/0091-7613(1995)023<1044:ECCALT>2.3.CO;2.

Grossman EL, Ku TL. 1986. Oxygen and carbon isotope fractionation in biogenic aragonite: temperature effects. Chemical Geology: Isotope Geoscience Section 59: 59-74. https://doi.org/10.1016/ 0168-9622(86)90057-6.

Guernet C, Huyghe D, Lartaud F, Merle D, Emmanuel L, Gély J-P, et al. 2012. Les ostracodes de la falunière de Grignon (Lutétien du bassin de Paris): implications stratigraphiques. Geodiversitas 34: 909-59. https://doi.org/10.5252/g2012n4a12.

Harzhauser M, Piller WE, Müllegger S, Grunert P, Micheels A. 2011. Changing seasonality patterns in Central Europe from Miocene Climate Optimum to Miocene Climate Transition deduced from the Crassostrea isotope archive. Global and Planetary Change 76: 7784. https://doi.org/10.1016/j.gloplacha.2010.12.003. 
Huber M, Goldner A. 2012. Eocene monsoons. Journal of Asian Earth Sciences 44: 3-23. https://doi.org/10.1016/j. jseaes.2011.09.014.

Huggett JM, Gale AS. 1997. Petrology and palaeoenvironmental significance of glaucony in the Eocene succession at Whitecliff Bay, Hampshire Basin, UK. Journal of the Geological Society 154: 897-912. https://doi.org/10.1144/gsjgs.154.5.0897.

Huyghe D, Merle D, Lartaud F, Cheype E, Emmanuel L. 2012a. Middle Lutetian climate in the Paris Basin: implications for a marine hotspot of paleobiodiversity. Facies 58: 587-604. https:// doi.org/10.1007/s10347-012-0307-3.

Huyghe D, Mouthereau F, Emmanuel L. 2012b. Oxygen isotopes of marine mollusc shells record Eocene elevation change in the Pyrenees. Earth and Planetary Science Letters 345-348: 131-141. https://doi.org/10.1016/j.eps1.2012.06.035.

Huyghe D, Lartaud F, Emmanuel L, Merle D, Renard M. 2015. Palaeogene climate evolution in the Paris Basin from oxygen stable isotope $\left(\delta^{18} \mathrm{O}\right)$ compositions of marine molluscs. Journal of the Geological Society 172: 576-87. https://doi.org/10.1144/ jgs2015-016.

Irie T, Suzuki A. 2020. High temperature stress does not distort the geochemical thermometers based on biogenic calcium carbonate: Stable oxygen isotope values and $\mathrm{Sr} / \mathrm{Ca}$ ratios of gastropod shells in response to rearing temperature. Geochimica et Cosmochimica Acta 288: 1-15. https://doi.org/10.1016/j.gca.2020.07.044.

Judd EJ, Wilkinson BH, Ivany LC. 2018. The life and time of clams: derivation of intra-annual growth rates from high-resolution oxygen isotope profiles. Palaeogeography, Palaeoclimatology, Palaeoecology 490: 70-83. https://doi.org/10.1016/j. palaeo.2017.09.034.

Kanduč T, Medakovíc D, Hamer B. 2011. Mytilus galloprovincialis as a bioindicator of environmental conditions: the case of the eastern coast of the Adriatic Sea. Isotopes in Environmental and Health Studies 47: 42-61. https://doi.org/10.1080/ 10256016.2011.548866.

Keith M, Anderson G, Eichler R. 1964. Carbon and oxygen isotopic composition of mollusk shells from marine and fresh-water environments. Geochimica et Cosmochimica Acta 28: 1757-1786.

King C. 2016. A revised correlation of Tertiary rocks in the British Isles and adjacent areas of NW Europe, 1st ed. Bath: The Geological Society of London.

Krantz DE, Williams DF, Jones DS. 1987. Ecological and paleoenvironmental information using stable isotope profiles from living and fossil molluscs. Palaeogeography, Palaeoclimatology, Palaeoecology 58: 249-266.

Kobashi T, Grossman EL, Yancey TE, Dockery III DT. 2001. Reevaluation of conflicting Eocene tropical temperature estimates: Molluskan oxygen isotope evidence for warm low latitudes. Geology 29: 983-986.

Kobashi T, Grossman EL. 2003. The oxygen isotopic record of seasonality in Conus shells and its application to understanding late middle Eocene (38 Ma) climate. Paleontological Research 7: 343-55. https://doi.org/10.2517/prpsj.7.343.

Kobashi T, Grossman EL, Dockery DT, Ivany LC. 2004. Water mass stability reconstructions from greenhouse (Eocene) to icehouse (Oligocene) for the northern Gulf Coast continental shelf (USA). Paleoceanography 19. https://doi.org/10.1029/2003pa000934.

Kohn AJ. 1959. The ecology of Conus in Hawaii. Ecological Monographs 29: 47-90.

Kohn AJ. 1961. Studies on spawning behavior, egg masses, and larval development in the gastropod genus Conus, Part I observations on nine species in Hawaii. Pacific Science XV: 163-79.
Kohn AJ. 1968. Microhabitats, abundance and food of Conus on Atoll reefs in the Maldive and Chagos Islands. Ecology 49: 1046-1062.

Lamarck J. 1804. Suite des mémoires sur les fossiles des environs de Paris. Annales du Muséum National d'Histoire Naturelle, 436-441.

Lambs L, Bompy F, Dulormne M. 2018. Using "isotopic spike” from tropical storm to understand water exchange on large scale: case study of Hurricane Rafael in the Lesser Antilles archipelago, October 2012. Rapid Communications in Mass Spectrometry 32: 457-468. https://doi.org/10.1002/rcm.8055.

Latal C, Piller WE, Harzhauser M. 2006. Shifts in oxygen and carbon isotope signals in marine molluscs from the central Paratethys (Europe) around the lower/middle Miocene transition. Palaeogeography, Palaeoclimatology, Palaeoecology 231: 347-60. https://doi.org/10.1016/j.palaeo.2005.08.008.

Lebrato M, Garbe-Schönberg D, Müller MN, Blanco-Ameijeiras S, Feely RA, Lorenzoni L, et al. 2020. Global variability in seawater $\mathrm{Mg}$ : $\mathrm{Ca}$ and Sr: Ca ratios in the modern ocean. Proceedings of the National Academy of Sciences 117: 22281-22292. https://doi.org/ 10.1073/pnas. 1918943117.

Lécuyer C, Reynard B, Martineau F. 2004. Stable isotope fractionation between mollusc shells and marine waters from Martinique Island. Chemical Geology 213: 293-305. https://doi. org/10.1016/j.chemgeo.2004.02.001.

Lécuyer C, Hutzler A, Amiot R, Daux V, Grosheny D, Otero O, et al. 2012. Carbon and oxygen isotope fractionations between aragonite and calcite of shells from modern molluscs. Chemical Geology 332-333: 92-101. https://doi.org/10.1016/j.chemgeo.2012.08.034.

Leviten PJ, Kohn AJ. 1980. Microhabitat resource use, activity patterns, and episodic catastrophe: Conus on tropical intertidal reef rock benches. Ecological Monographs 50: 55-75.

McConnaughey TA, Gillikin DP. 2008. Carbon isotopes in mollusk shell carbonates. Geo-Marine Letters 28: 287-99. https://doi.org/ 10.1007/s00367-008-0116-4.

Mégnien C, Mégnien F. 1980. Stratigraphie et paléogéographie. In: Mégnien C, ed. Synthèse Géologique du Bassin de Paris, pp. 1-466.

Melville R, Freshney E. 1982. British regional geology; the Hampshire Basin and adjoining areas, 4th ed. London: H.M.S.O.

Merle D. 2008. Stratotype Lutétien, 1st ed. Paris : Muséum national d'Histoire naturelle; Biotope, Mèze; BRGM, Orléans.

Mosbrugger V, Utescher T, Dilcher DL. 2005. Cenozoic continental climatic evolution of Central Europe. Proceedings of the National Academy of Sciences 102: 14964-14969. https://doi.org/10.1073/ pnas.0505267102.

Murray J, Wright C. 1974. Palaeogene Foraminiferida and palaeoecology, Hampshire and Paris Basins and the English Channel. Special Papers in Palaeontology 14: 1-129.

Norvick MS. 1969. An analysis of the microfauna and microflora of the upper Eocene of the Hampshire Basin. University of London.

Plint AG. 1982. Eocene Sedimentation and Tectonics in the Hampshire Basin (UK). Journal of the Geological Society 139: 249-54. https://doi.org/10.1144/gsjgs.139.3.0249.

Plint AG. 1983. Facies, environments and sedimentary cycles in the middle Eocene, Bracklesham Formation of the Hampshire Basin: evidence for global sea-level changes? Sedimentology 30: 625-53. https://doi.org/10.1111/j.1365-3091.1983.tb00699.x.

Plint AG. 1988. Global eustacy and the Eocene sequence in the Hampshire Basin, England. Basin Research 1: 11-22.

Pomerol C. Stratigraphie et paléogéographie. In: Pomerol C, ed. Ere Cénozoïque, 1973.

Poulain C, Gillikin DP, Thébault J, Munaron JM, Bohn M, Robert R, et al. 2015. An evaluation of $\mathrm{Mg} / \mathrm{Ca}, \mathrm{Sr} / \mathrm{Ca}$, and $\mathrm{Ba} / \mathrm{Ca}$ ratios as environmental proxies in aragonite bivalve shells. Chemical 
Geology 396: 42-50. https://doi.org/10.1016/j.chem geo.2014.12.019.

Purton LMA. 1997. Geochemical approaches to the problem of nummulitic life habit and habitat in the Eocene. Oxford University.

Purton LMA, Brasier MD. 1997. Gastropod carbonate $\delta^{18} \mathrm{O}$ and $\delta^{13} \mathrm{C}$ values record strong seasonal productivity and stratification shifts during the late Eocene in England. Geology 25: 871. https://doi.org/ 10.1130/0091-7613(1997)025<0871:GCOACV>2.3.CO;2.

Purton LMA, Shields GA, Brasier MD, Grime GW. 1999. Metabolism controls $\mathrm{Sr} / \mathrm{Ca}$ ratios in fossil aragonitic mollusks. Geology 27: 1083-1086. https://doi.org/10.1130/0091-7613(1999) 027<1083:MCSCRI>2.3.CO;2.

Rae JWB, Zhang YG, Liu X, Foster GL, Stoll HM, Whiteford RDM. 2021. Atmospheric $\mathrm{CO}_{2}$ over the past 66 million years from marine archives. Annual Review of Earth and Planetary Sciences 49. https://doi.org/10.1146/annurev-earth-082420-063026.

Sanders MT, Merle D, Villier L. 2015. The molluscs of the "Falunière" of Grignon (Middle Lutetian, Yvelines, France): quantification of lithification bias and its impact on the biodiversity assessment of the Middle Eocene of Western Europe. Geodiversitas 37: 345-365. https://doi.org/10.5252/g2015n3a4.

Schmitz B, Andreasson FP. 2001. Air humidity and lake $\delta^{18} \mathrm{O}$ during the latest Paleocene-earliest Eocene in France from recent and fossil fresh-water and marine gastropod $\delta^{18} \mathrm{O}, \delta^{13} \mathrm{C}$, and ${ }^{87} \mathrm{Sr} /{ }^{86} \mathrm{Sr}$. Geological Society of America Bulletin 113: 774-89. https://doi. org/10.1130/0016-7606(2001)113<0774:AHALOD>2.0.CO;2.

Sosdian S, Gentry DK, Lear CH, Grossman EL, Hicks D, Rosenthal Y. 2006. Strontium to calcium ratios in the marine gastropod Conus ermineus: growth rate effects and temperature calibration. Geochemistry, Geophysics, Geosystems 7: 1-17. https://doi.org/ 10.1029/2005GC001233.

Speijer RP, Pälike H, Hollis CJ, Hooker JJ, Ogg JG. 2020. The Paleogene Period. In: Gradstein FM, Ogg JG, Schmitz MD, Ogg GM, eds. Geologic Time Scale 2020, pp. 1087-1140. https://doi. org/10.1016/b978-0-12-824360-2.00028-0.

Stinton FC. 1969. Field meeting in the New Forest, Hants. Proceedings of the Geologists' Association 81: 269-274.

Swart P, Price R. 2002. Origin of salinity variations in Florida Bay. Limnology and Oceanography 47: 1234-1241.

Swart P, Sternberg L, Steinen R, Harrison S. 1989. Controls on the oxygen and hydrogen isotopic composition of the waters of Florida Bay, U.S.A. Chemical Geology: Isotope Geoscience Section 79: 113-123.

Tao K, Grossman EL. 2010. Origin of high productivity in the Pliocene of the Florida platform: evidence from stable isotopes and trace elements. Palaios 25: 796-806. https://doi.org/10.2110/ palo.2010.p10-058r.

Tao K, Robbins JA, Grossman EL, O’Dea A. 2013. Quantifying upwelling and freshening in nearshore tropical American environments using stable isotopes in modern gastropods. Bulletin of
Marine Science 89: 815-35. https://doi.org/10.5343/ bms.2012.1065.

Thiry M. 1989. Geochemical evolution and paleoenvironments of the Eocene continental deposits in the Paris Basin. Palaeogeography, Palaeoclimatology, Palaeoecology 70: 153-63. https://doi.org/ 10.1016/0031-0182(89)90086-2.

Tierney JE, Poulsen CJ, Montañez IP, Bhattacharya T, Feng R, Ford HL, et al. 2020. Past climates inform our future. Science 370: eaay3701. https://doi.org/10.1126/science.aay3701.

Tivollier J, Létolle R, Pomerol C. 1968. Résultats et interprétation d'analyses isotopiques de faunes malacologiques du Tertiaire parisien. In: Pomerol C, ed. Colloque sur l'Eocène, pp. 346-357.

Tracey S, Todd J, Le Renard J, King C, Goodchild M. 1996. Distribution of Mollusca in units S1 to S9 of the Selsey Formation (Middle Lutetian), Selsey Peninsula, West Sussex. Tertiary Research 16: 97-140.

Tracey S, Craig B, Belliard L, Gain O. 2017. One, four or forty species?-Early Conidae (Mollusca, Gastropoda) that led to a radiation and biodiversity peak in the late Lutetian Eocene of the Cotentin, NW France. In: Le Renard J, ed. Carnet de Voyages Paléontologiques dans le Bassin Anglo-Parisien, Tome 3, pp. 1-38.

Tucker J, Tenorio M. 2009. Systematic classification of recent and fossil conoidean gastropods: with keys to the genera of cone shells. Hackenheim: Conchbooks.

van Hinsbergen DJJ, de Groot LV, van Schaik SJ, Spakman W, Bijl PK, Sluijs A, et al. 2015. A paleolatitude calculator for paleoclimate studies (model version 2.1). PLoS one 10: e 0126946.

Van Horebeek N, Vellekoop J, Clark AJ, de Winter NJ, Speijer RP. 2021. A stable oxygen isotope record of weather-timescale variability in the Eocene greenhouse world, using the giant marine gastropod Campanile giganteum. EGU General Assembly 2021.

Van Vliet-Lanoë B, Gosselin G, Mansy J-L, Bourdillon C, MeurisseFort M, Henriet J-P, et al. 2010. A renewed Cenozoic story of the Strait of Dover. Annales de La Société Géologique du Nord 17 (2):59-80.

Vander Zanden MJ, Rasmussen JB. 2001. Variation in $\delta^{15} \mathrm{~N}$ and $\delta^{13} \mathrm{C}$ trophic fractionation: implications for aquatic food web studies. Limnology and Oceanography 46: 2061-66. https://doi.org/ 10.4319/lo.2001.46.8.2061.

Westerhold T, Marwan N, Drury AJ, Liebrand D, Agnini C, Anagnostou E, et al. 2020. An astronomically dated record of Earth's climate and its predictability over the last 66 million years. Science 369: 1383-1387. https://doi.org/10.1126/science.aba6853.

Zachos J, Stott L, Lohmann K. 1994. Evolution of early Cenozoic marine temperatures. Paleoceanography 9: 353-387.

Zachos JC, Dickens GR, Zeebe RE. 2008. An early Cenozoic perspective on greenhouse warming and carbon-cycle dynamics. Nature 451: 279-83. https://doi.org/10.1038/nature06588.

Cite this article as: Clark AJ, Vellekoop J, Speijer RP. 2022. Hydrological differences between the Lutetian Paris and Hampshire basins revealed by stable isotopes of conid gastropods, BSGF - Earth Sciences Bulletin 193: 3. 